\title{
Portal hypertension and ascites in systemic mastocytosis
}

\author{
M.N. Narayanan, J.A. Liu Yin, S. Azzawi, T.W. Warnes ${ }^{1}$ and W.P.G. Turck ${ }^{2}$
}

Department of Clinical Haematology and ${ }^{1}$ Gastroenterology, The Royal Infirmary, Manchester and ${ }^{2}$ Department Medicine, Bury General Hospital, Bury, UK.

\begin{abstract}
Summary: We report a case of systemic mastocytosis (SM) presenting as ascites and portal hypertension. The haematological picture at presentation was suggestive of chronic myelomonocytic leukaemia. Initial difficulties in making a diagnosis of SM were encountered as the cutaneous signs were atypical. The correct diagnosis was established only after tissue sections were appropriately stained for mast cells. The liver biopsy showed portal and sinusoidal mast cell infiltration, portal fibrosis and evidence of hepatic venous outflow obstruction. The disease progressed rapidly and recurrent massive ascites was a dominant problem. This case illustrates again the problems of making a diagnosis of SM especially when the clinical picture is atypical. Ascites as a presenting manifestation of SM has been reported previously in only six patients. Published cases of SM with portal hypertension or ascites or both are reviewed.
\end{abstract}

\section{Introduction}

Systemic mastocytosis $(\mathbf{S M})$ is a rare disease characterized by the proliferation of mast cells in skin, bones, lymph nodes and parenchymal organs. ${ }^{1,2}$ The cutaneous form, urticaria pigmentosa, is the most common mastocytosis. Portal hypertension and ascites are rare manifestations of $\mathrm{SM}^{3-9}$ (Table I). A review of English language publications revealed that ascites as a presenting feature of SM has been reported in only 6 patients. ${ }^{4.8 .9}$ We describe a patient with SM who presented with ascites and discuss the problems of making a correct diagnosis in the absence of typical cutaneous signs.

\section{Case report}

A previously well 49 year old male presented with a 6-week history of cough, general weakness and night sweats. Clinical examination showed pallor, low grade pyrexia, a punctate erythematous rash around the neck, ascites and hepatomegaly. Investigations showed: haemoglobin $11.1 \mathrm{~g} / \mathrm{dl}$, white cell count $11.3 \times 10^{9} / 1$ (neutrophils $59 \%$, lymphocytes $14 \%$, monocytes $19 \%$, myelocytes $8 \%$ ), platelets $77 \times 10^{9} / 1$, ESR $50 \mathrm{~mm} / 1 \mathrm{~h}$. Liver function tests demonstrated hepatocellular impairment with a serum albumin varying from $27-32 \mathrm{~g} / \mathrm{l}$ and a prolonged prothrombin time at 19 seconds (control 14 seconds); serum alkaline phosphatase was also raised at $56 \mathrm{KA} \mathrm{U} / \mathrm{dl}$ (liver

Correspondence: M.N. Narayanan, M.R.C.P., M.R.C.Path., Department of Clinical Haematology, Royal Infirmary, Manchester M13 9WL, UK.

Accepted: 21 December 1988 origin on isoenzyme fractionation). Computed tomo graphic scan of the abdomen showed hepatosplenomegaly and a possible mass anterior to the left kidney the appearances were suggestive of lymphoma. Ascitio fluid protein content was $41 \mathrm{~g} / \mathrm{l}$; on cytology seresat cells and macrophages but no malignant cells wife seen.

At laparotomy 10 litres of straw coloured fluid wie obtained but there was no evidence of intra-abdominat malignancy. The liver felt cirrhotic and the spleen was enlarged. The liver biopsy showed periportal fibrosio with mild inflammatory cell infiltration, extramedu?

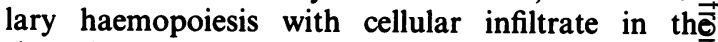
sinusoids suggestive of myeloid leukaemia, and cen $₹$ trilobular cell loss and congestion consistent wit hepatic venous outflow obstruction. Postoperativel. the ascites recurred.

There was no evidence of varices on endoscopy? Isotope liver scan showed nonspecific changes? Skeletal survey showed generalized bony sclerosis. Hepatic vein catheterization via the antecubital route showed patent hepatic veins with a raised (corrected? wedge hepatic vein pressure $(17 \mathrm{mmHg})$, consistent with a sinusoidal or postsinusoidal type of portaf hypertension. Mild anaemia persisted and the white cell count rose to $20 \times 10^{9} / 1$, with a monocyte count of $2 \times 10^{9} / 1$. Serum lysozyme was raised at $34 \mathrm{mg} / \mathrm{l}$. The bone marrow was markedly hypercellular with hyperplasia of the granulocytic series and excess of monocytes; karyotypic examination was normal. tentative diagnosis of chronic myelomonocytie leukaemia was made.

However, subsequent histological review of the liver biopsy stained with toluidine blue (Prof P. Scheuer

(C) The Fellowship of Postgraduate Medicine, $198 \%$ 
Table I Portal hypertension and ascites in systemic mastocytosis

\begin{tabular}{|c|c|c|c|c|c|c|}
\hline References & $\begin{array}{l}\text { Ascites at } \\
\text { diagnosis }\end{array}$ & $\begin{array}{c}\text { Ascites } \\
\text { years after } \\
\text { diagnosis }\end{array}$ & $P H$ & $\begin{array}{l}\text { Age/ } \\
\text { Sex }\end{array}$ & $\begin{array}{l}\text { Mechanism } \\
\text { of ascites }\end{array}$ & $\begin{array}{l}\text { Mechanism } \\
\text { of } P H\end{array}$ \\
\hline Zak $(1957)^{3}$ & no & yes & unknown & $58 \mathrm{~F}$ & unknown & NA \\
\hline Bloom $(1960)^{4}$ & yes & NA & unknown & $47 \mathrm{~F}$ & MCI & NA \\
\hline Capron $(1978)^{5}$ & no & no & yes & $66 \mathrm{M}$ & NA & $\dagger \mathrm{PF}+\mathrm{MCI}$ \\
\hline Grundfest $(1980)^{6}$ & no & no & yes & $55 \mathrm{M}$ & NA & SBF \\
\hline Sawers $(1982)^{7}$ & no & yes & yes & $51 \mathrm{M}$ & $\mathrm{PH}+\mathrm{HCDF}$ & $\mathrm{PF}+\mathrm{MCI}$ \\
\hline Ghandur-Mnaymneth $(1985)^{8}$ & yes & NA & yes & $51 \mathrm{M}$ & PH + HCDF & $\begin{array}{c}\mathrm{PF}+\mathrm{MCI}+ \\
\text { SECD }\end{array}$ \\
\hline $\begin{array}{l}\text { Yam }(1986)^{9} \\
\text { Narayanan } \\
\text { (current study) }\end{array}$ & $\begin{array}{l}4 \dagger \\
\text { yes }\end{array}$ & $\begin{array}{c}1 \dagger \\
\text { NA }\end{array}$ & $\begin{array}{l}\text { ND } \\
\text { yes }\end{array}$ & $\begin{array}{l}\text { ND } \\
49 M\end{array}$ & $\begin{array}{c}\text { ND }^{*} \\
\text { PH + HCDF }\end{array}$ & $\begin{array}{c}\text { ND } \\
\mathrm{PF}+\mathrm{MCI}+ \\
\mathrm{HVOB}\end{array}$ \\
\hline
\end{tabular}

NA, not applicable; PF, portal fibrosis; $\mathrm{MCI}$, mast cell infiltration; SBF, splenic blood flow; PH, portal hypertension; HCDF, hepatocellular dysfunction; SECD, subendothelial collagen deposition; ND, no details of individual patients available; ${ }^{*}$ one patient had diffuse involvement by mast cells of peritoneum and omentum; $\uparrow$ number of patients; HVOB, hepatic venous outflow block.

Royal Free Hospital) showed significant mast cell infiltration in the portal tracts. The diagnosis of SM was confirmed by the demonstration of mast cell infiltration in the bone marrow trephine biopsy, splenunculus (removed at laparotomy) and skin biopsy.

Initially the patient's ascites responded to medical management consisting of abdominal paracentesis and chemotherapy with 6-mercaptopurine and hydroxyurea. Subsequently the ascites recurred and proved very resistant to therapeutic intervention. Eventually the patient developed cachexia, intractable ascites and peptic ulceration and died of bronchopneumonia, 8 months after the diagnosis was made.

Autopsy showed bronchopneumonia, ascites and duodenal ulcers with old perforation. The spleen showed mast cell infiltration, multiple infarcts and residual fibrosis. The liver showed centrilobular necrosis, expanded portal tracts and bile ductule proliferation. The lymph nodes showed extensive infiltration by mast cells.

\section{Discussion}

Hepatic involvement is common in SM. Asymptomatic hepatomegaly was present in 10 out of 13 cases in one series. ${ }^{9}$ Mast cell infiltration of the liver was present in all 13 cases in one report ${ }^{9}$ and in 14 out of 17 cases in another. ${ }^{1}$ Results of liver function tests are variable but serum alkaline phosphatase was elevated in all 13 patients in one report. ${ }^{9}$

Portal hypertension in SM was first reported in $1978 .^{5}$ Since then 3 more cases of SM with portal hypertension have been described ${ }^{6-8}$ (Table I). In 3 other cases of SM with ascites, it is uncertain whether portal hypertension was present or not. ${ }^{3,4,9}$ The portal hypertension was thought to be due to increased splenic blood flow in one case ${ }^{6}$ where the portal pressure returned to normal following splenectomy. Increased splenic blood flow was thought to be a contributory factor in another case. ${ }^{7}$ Presinusoidal and sinusoidal block due to mast cell infiltration and resulting fibrosis was thought to be the main mechanism of portal hypertension in 3 cases. ${ }^{5,7,8}$ Subendothelial collagen deposition was demonstrated in hepatic sinusoids at electron microscopy in one case. ${ }^{8}$ In our case there was portal and sinusoidal mast cell infiltration and fibrosis. In addition there was evidence of hepatic venous outflow block occurring in the small hepatic vein radicles presumably due to MC infiltration and fibrosis. It may be that the mechanisms of portal hypertension in SM are not necessarily the same in all cases.

$\mathrm{Zak}^{3}$ reported a case of SM where the patient developed ascites during the course of the illness. Since then 8 more cases of SM with ascites have been reported, ${ }^{4,7-9}$ six of these presented with ascites,8,9 and 2 developed ascites during the course of their disease. ${ }^{79}$ Two patients had diffuse infiltration of peritoneum and omentum by mast cells ${ }^{4,9}$ which was thought to be directly responsible for the ascites. A combination of hepatocellular dysfunction together with portal hypertension was thought to be the mechanism of ascites in 3 cases including ours. The mechanisms involved are uncertain in 2 other cases. ${ }^{3,9}$ The salient features of these cases are summarized in Table I.

Difficulty in diagnosing SM in the absence of urticaria pigmentosa is well known. ${ }^{10}$ In our patient the skin rash was atypical and therefore overlooked. The other diagnoses considered at presentation were chronic myeloid leukaemia, lymphoma and car- 
cinomatosis. The anaemia, blood and marrow monocytosis, granulocytic hyperplasia and high serum lysozyme level suggested a diagnosis of chronic myelomonocytic leukaemia. ${ }^{11,12}$ Seventeen percent of patients with SM in one series ${ }^{10}$ had monocytosis and granulocytic hyperplasia was found frequently in bone marrow aspirates. Three cases in another series of SM were diagnosed as myelomonocytic leukaemia based on haematological and clinical findings. ${ }^{13}$ One case ${ }^{7}$ was diagnosed as myelofibrosis initially and the true diagnosis of SM was made only 10 years later from liver and bone marrow biopsies. Differentiation of SM from other myeloproliferative disorders depends on the demonstration of mast cell infiltration in bone marrow or other organs using appropriate cyto-

\section{References}

1. Lennert, K. \& Parwaresch, M.R. Mast cells and mast cell neoplasia: a review. Histopathology 1979, 3: 349-365.

2. Tharp, M.D. The spectrum of mastocytosis. Am J Med Sci 1985, 289: 119-132.

3. Zak, F.G., Covey, J.A. \& Shodgrass, J.J. Osseous lesions in urticaria pigmentosa. $N$ Engl J Med 1957, 256: 56-62.

4. Bloom, G., Franzen, S. \& Siren, M. Malignant systemic mast cell disease (mastocytoma) in man. Acta Med Scand 1960, 168: 95-102.

5. Capron, J.P., Lebrec, D., Degott, C. Chivrac, D., Coevoet, B. \& Delobel, J. Portal hypertension in systemic mastocytosis. Gastroenterology 1978, 74: 595-597.

6. Grundfest, S., Cooperman, A.M., Ferguson, R. \& Benjamin, S. Portal hypertension associated with systemic mastocytosis and splenomegaly. Gastroenterology 1980, 78: 370-373.

7. Sawers, A.H., Davson, J., Braganza, J. \& Geary, C.G. Systemic mastocytosis, myelofibrosis and portal hypertension. J Clin Pathol 1982, 35: 617-619. chemical techniques and aided by a high index suspicion.

Although ascites was a dominant feature in oưf patient, the eventual deterioration and death were duti to the general effects of cachexia, peptic ulceration, perforation and sepsis. This is consistent with the observation that the prognosis in SM is related to the systemic effects of mast cell involvement in mang organs.

\section{Acknowledgements}

The authors thank Prof P.J. Scheuer and Dr N.Y. Haboub for their help in establishing the diagnosis.

8. Ghandur-Mnaymneth, L. \& Gould, E. Systemic mas tocytosis with portal hypertension. Autopsy findings an ultrastructural study of the liver. Arch Pathol Lab Med 1985, 109: 76-78.

9. Yam, L.T., Chan, C.H. \& Li, C.Y. Hepatic involvememt in systemic mast cell disease. Am J Med 1986, 80, 819-826.

10. Webb, T.A., Li, C.Y. \& Yam, L.T. Systemic mast ce disease: a clinical and haematopathologic study of cases. Cancer 1982, 49: 927-938.

11. Geary, C.G., Catovsky, D., Wiltshaw, et al. Chring myelomonocytic leukaemia. Br J Haematol 197530: 289-302.

12. Skinnider, L.F., Card, R.T. \& Padmanabh, S. Chrơn myelomonocytic leukaemia. Am J Clin Pathol 1977, 6 . 339.

13. Horny, H.P. Parwaresch, M.R. \& Lennert, K. Boo marrow findings in systemic mastocytosis. Hum Patha 1985, 16: 808-814. 